\title{
A new species of Erioptera Meigen, 1803 (Diptera: Limoniidae) from Krasnodar Territory
}

\author{
Новый вид Erioptera Meigen, 1803 (Diptera: Limoniidae) \\ из Краснодарского края
}

\author{
D.I. Gavryushin \\ А.И. Гаврюшин \\ Zoological Museum, Moscow Lomonosov State University, Bol'shaya Nikitskaya 6, Moscow 125009 Russia. E-mail: \\ dmitry_gavryushin@yahoo.com \\ Зоологический музей, Московский государственный университет им. М.В. Ломоносова, Большая Никитская ул., 6, Москва \\ 125009 Россия \\ KEYWORDS: Diptera, Limoniidae, Erioptera, Russia, Krasnodar Territory, Caucasus, taxonomy, descrip- \\ tion, new species \\ КЛЮЧЕВЫЕ СЛОВА: Diptera, Limoniidae, Erioptera, Россия, Краснодарский край, Кавказ, таксономия, \\ описание, новый вид
}

ABSTRACT. A new species of Erioptera Meigen, 1803 is described from Krasnodar Territory, Russia. Descriptions of both sexes, illustrations of male and female terminalia as well as remarks on ecology are provided.

РЕЗЮМЕ. Описан новый вид рода Erioptera Meigen, 1803 из Краснодарского края (Россия). Даны описания обоих полов, иллюстрации терминалий самца и самки, а также заметки об экологии.

\section{Introduction}

While studying short-palped craneflies (Limoniidae) collected by the author in 2009 and 2010 in the environs of Adler (Russia, Krasnodar Territory), a species new to science belonging to the nominative subgenus of the genus Erioptera Meigen, 1803 (subfam. Chioneinae) was discovered. The subgenus Erioptera s.str. includes more than 140 valid species and subspecies; about $35 \%$ of these are distributed in the Palaearctic region [Oosterbroek, 2011]; 20 species and subspecies are known from Europe [Oosterbroek, 2010]. A total of 21 taxons is recorded from Russia so far. The main diagnostic features of the subgenus are as follows: cell $D$ open due to the atrophy of vein $m-q u$ and fused with cell $M_{2}$, vein $a_{2}$ long and sinuous, cell $A_{1}$ usually wider at middle than at wing margin, tergite 9 in male with big median projection apically.

\section{Material and methods}

The morphological terms used here mainly follow McAlpine [1981], while venation is described mostly according to the terminology in Savchenko [1986]; some terms for description of the aedeagal complex are adopted from Starý [2009]. Details of colouration were checked in dry-mounted specimens only. Male genitalia and female ovipositors were boiled in $10 \%$ solution of potassium hydroxide (KOH) for 60 to $90 \mathrm{~s}$, neutralised by a $10 \%$ solution of acetic acid $\left(\mathrm{CH}_{3} \mathrm{COOH}\right)$, washed in water and then stored in glycerine. Wing of a male in ethanol and insects in nature were photographed with a Nikon D70s DSLR camera; microphotographs of genitalia were prepared using an eTREK DCM900 camera on MBI-1 microscope and processed with CombineZP software. Type material is deposited in the Zoological Museum of the Moscow State University (ZMUM).

\section{Species description}

\section{Erioptera octobris sp.n.}

Figs 1-11.

MATERIAL EXAMINED. Holotype $\sigma^{7}$, RUSSIA: Krasnodar Territory, Sochi/Adler $\left(43.4766^{\circ} \mathrm{N}, 39.9067^{\circ} \mathrm{E}\right), 18 . X .2010$, D. Gavryushin (dry-mounted, glued to an insect pin; in very good condition). Paratypes: dry-mounted specimens: $1 \sigma^{7}$, RUSSIA: Krasnodar Territory, env. of Adler, $43.4753^{\circ} \mathrm{N}, 39.8991^{\circ} \mathrm{E}, 21 . X .2009$; $1 \sigma^{\top}$, RUSSIA: Krasnodar Territory, Sochi/Adler $\left(43.4766^{\circ} \mathrm{N}\right.$,

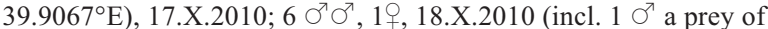
Blepharicera sp.); 1 \% , 1 ㅇ (in copula), 20.X.2010 (D. Gavryushin); specimens in 70\% ethanol: $1 \sigma^{7}, 1 \%$, RUSSIA: Krasnodar Territory, Sochi/Adler $\left(43.4766^{\circ} \mathrm{N}, 39.9067^{\circ} \mathrm{E}\right), 15 . X .2010 ; 6 \sigma^{\top} \sigma^{7}$, 2 우, 18.X.2010 (D. Gavryushin).

DIAGNOSIS. The new species is similar to a number of yellow species with dark palpi and without finger-like dorso-mesal process at the apex of gonocoxites (E. nielseni de Meijere, 1921, E. griseipennis Meigen, 1838, E. verralli Edwards, 1921) but differs in structure of male genitalia. 


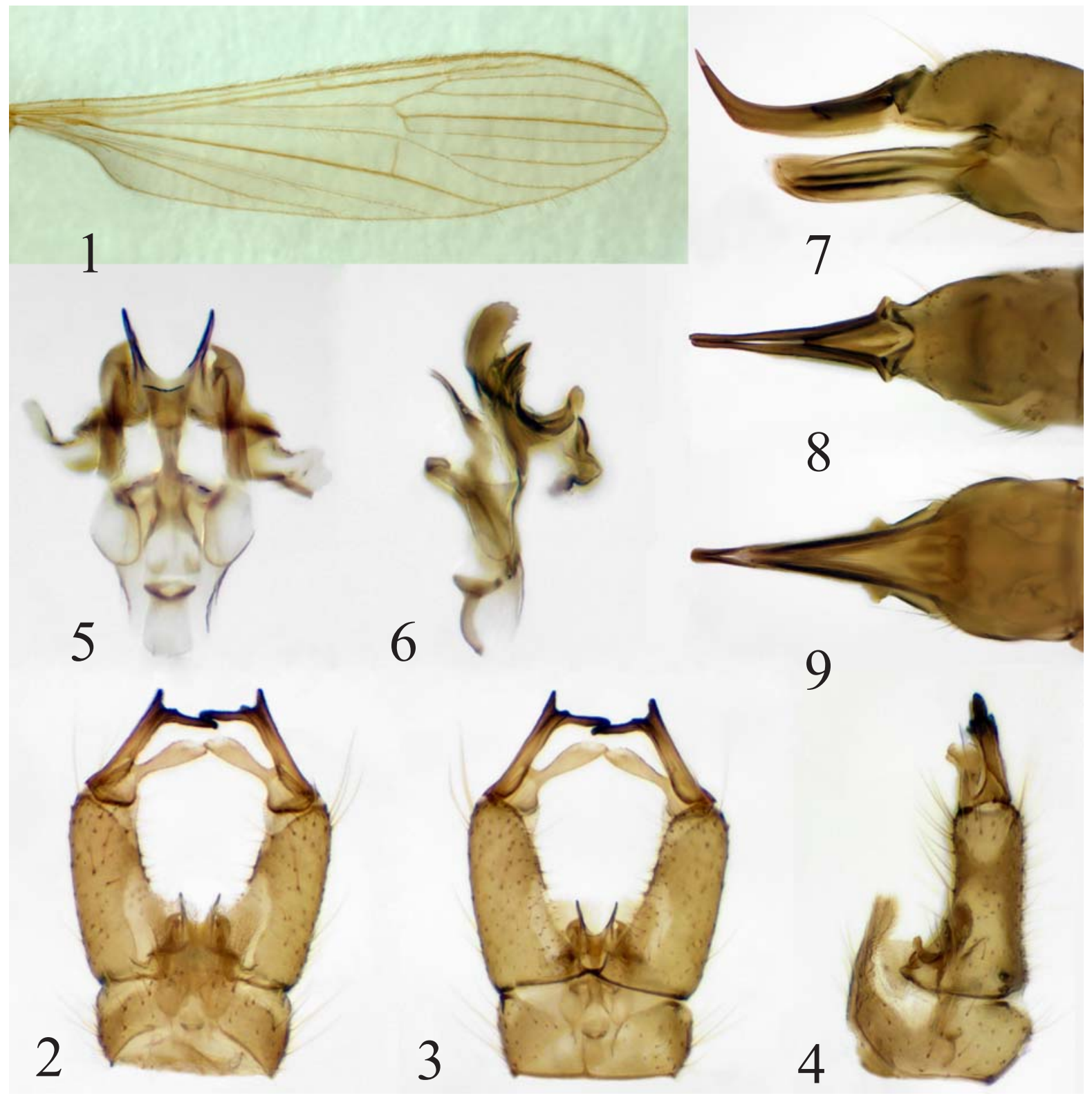

Figs 1-9. Erioptera octobris sp.n.: 1 - male wing; 2 - male hypopygium, dorsal view; 3 - same, ventral view; 4 - same, lateral view; 5 - aedeagal complex, dorsal view; 6 - same, lateral view; 7 - ovipositor, lateral view; 8 - same, dorsal view; 9 - same, ventral view.

Pис. 1-9. Erioptera octobris sp.n.: 1 - крыло самца; 2 - гипопигий самца, вид сверху; 3 - то же, вид снизу; 4 - то же, вид сбоку; 5 - эдеагус, вид сверху; 6 - то же, вид сбоку; 7 - яйцеклад, вид сбоку; 8 - то же, вид сверху; 9 - то же, вид снизу.

DESCRIPTION. Male. Medium-sized species within Erioptera (s. str.). General colouration yellow, only eyes black. Body length ca. $4 \mathrm{~mm}$, wing length ca. $5 \mathrm{~mm}$.

Head yellow with gray pollinosity, vertex with a few long hairs, rostrum and palpi dark brown. Antennae yellow with brownish pollinosity, verticillate, if bent backwards not reaching the root of the wings; $1 \mathrm{st}$ flagellomere short, almost elliptical, other flagellomeres elongated, almost cylindrical, becoming thinner to the apex of antennae, 3 apical segments roughly 3.5 times as long as wide; flagellomeres with yellowish pubescence (length of hairs approx. equal to width of segments) and dark verticils roughly equal in length to corresponding segments.

Thorax brownish-yellow, the dorsal surface somewhat darker, praescutum with an indistinct dark median stripe, paratergite and postpronotum paler, almost light yellow. Tuberculate pits conspicuous, dark against the background of praescutum. Antepronotum with 1 pair of long dark hairs in medio-lateral position and 1-2 pairs of shorter dark hairs more laterally. 3 dark 


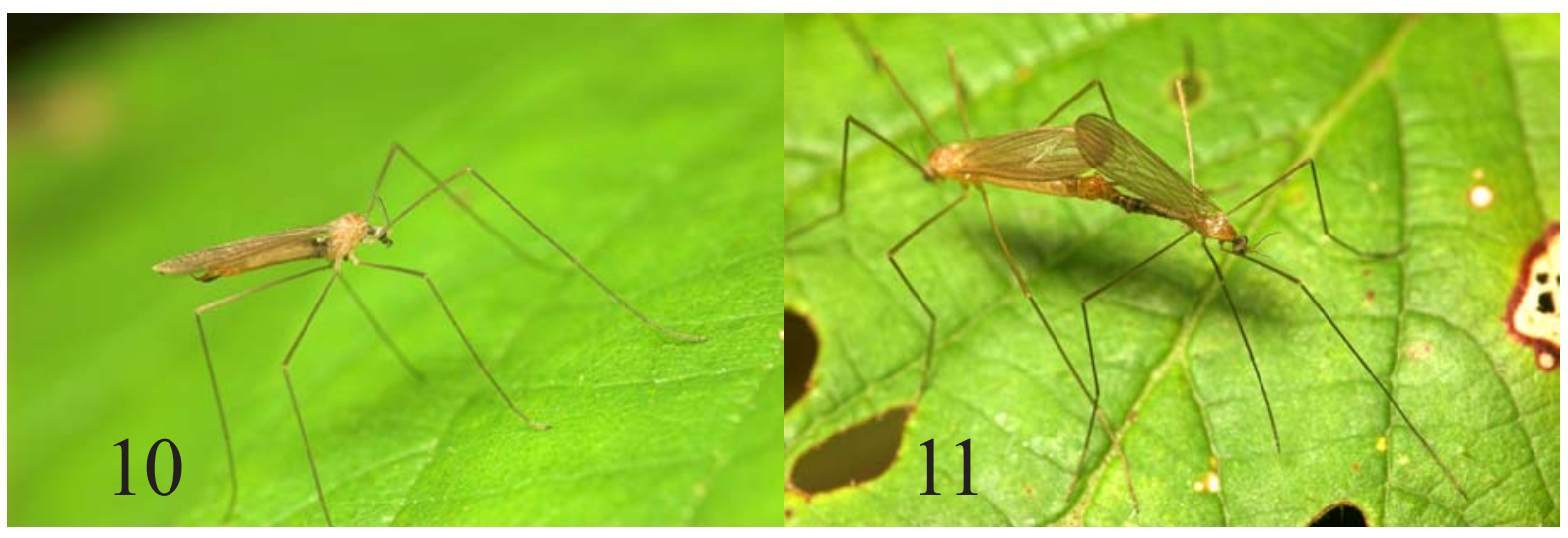

Figs 10-11. Erioptera octobris sp.n.: 10 - female; 11 - pair in copula.

Рис. 10-11. Erioptera octobris sp.n.: 10 - самка; 11 - спаривающаяся пара.

hairs above fore coxae. Praescutum with 2 medio-lateral rows of 5 dark hairs, lobes of praescutum with similar rows of stronger hairs and with several dark hairs at the posterior margin, scutellum with about 10 dark hairs. Katepisternum, upper part of anepimeron, metepisternum and posterior margin of laterotergite with sparse long yellowish hairs. Halteres yellow, densely covered with hairs, stem rather long, knob somewhat darkened. Legs long, yellow, distal part of tarsi appears darker because of dense hairs; coxae and trochanters with long dark hairs.

Wings (Fig. 1) of moderate width, wing membrane hyaline, suffused with yellow, veins yellow with dark hairs (roughly equal in length to crossvein $r-m$ ), posterior margin of wings with a fringe of like hairs. Squamae with dark sclerotised area in upper part. Venation as in the subgenus; $s c_{1}$ ending opposite $r q, s c_{2}$ at about half the length of $r s, m-c u$ slightly before the point of furcation of $m$.

Abdomen cylindrical, with yellowish hairs, tergites brown dorsally, paling into the yellow laterally, sternites yellow; sometimes abdomen completely brown. Hypopygium (Figs 2-4) rather big, yellow. Tergite 9 transverse, its apex with a big dorso-mesal membraneous process divided in two rounded lobes for approx. one third of its length and covered with short fine hairs. Gonocoxites almost cylindrical, 3 times as long as wide. Gonostyli in terminal position, upper (outer) gonostyli rod-like, of moderate length, with dark-pigmented distal part having three processes, dorsal process triangular, median process short, rounded, ventral process the longest of the three (approx. 0.4 length of gonostylus), slightly curved, triangular; apices of these processes faintly serrated. Lower (inner) gonostyli a little longer than outer ones, spathulate with wide basal part and small conical protrusion at the base dorsally; apical part with transverse notches; short hairs on inner surface and at apex. Aedeagal complex (Figs 5-6) of complicated structure, big, elongated. Penis short, its apex with a triangular incision. Parameres of two lobes; inner lobes thin, dilated, rounded apically, with serrated edges; outer lobes stout, with two pointed beak-like apices, one curved inwards and another at a right angle to it. Vesica ovoid, apodeme large, curved, broad distally. Two appendages around the base of penis form an incomplete semicircular bridge.

Female. Body length ca. $5 \mathrm{~mm}$, wing length ca. 6 $\mathrm{mm}$. General colouration somewhat paler than in male. Abdomen uniformly reddish-yellow, ovipositor (Figs 7-9) concolorous with abdomen, with long cerci curved upwards, forming triangular tubercles at the point of articulation with tergite 10 ; hypogynial valvae shorter and stouter.

ETYMOLOGY. From the Latin adjective "octobris" (sg. fem. nom.), meaning "of October", since all the material was collected in mid- and late October.

NOTES ON ECOLOGY. This species was rather common throughout the day and in various weather conditions at the edge of deciduous forest (Carpinus/ Fagus) among herbaceous vegetation and Rubus brushes, either flying or sitting on leaves and bark of trees (Figs 10-11). One male was recorded as prey of a male Blepharicera sp. (Blephariceridae).

ACKNOWLEDGEMENTS. I wish to express my sincere gratitude to Dr. Jaroslav Starý (Palacký University, Olomouc, Czech Republic) for attracting my attention to this new species and kind assistance with identification of Limoniidae from various regions, Dr. Andrey L. Ozerov (ZMUM) who helped a lot in mastering a technique of microphotograph preparation as well as contributed numerous corrections to significantly improve this article, and Dr. Nikita E. Vikhrev (ZMUM) for continuing support and organising collecting trips to Sochi/Adler area in 2007, 2008, 2009 and 2010.

\section{References}

McAlpine J.F. 1981. Morphology and terminology — adults // J.F. McAlpine et al. (eds.). Manual of Nearctic Diptera 1. Research Branch, Agriculture Canada, Ottawa. Monograph No.27. P.963.

Oosterbroek P. 2010. Fauna Europaea: Limoniidae // P. Beuk \& T. Pape (eds.) (2010) Fauna Europaea: Diptera. Fauna Europaea 
version 2.3, online at: http://www.faunaeur.org (accessed January 25,2011$)$.

Oosterbroek P. 2011. Catalogue of the Craneflies of the World (Diptera, Tipuloidea: Pediciidae, Limoniidae, Cylindrotomidae, Tipulidae), online at: http://nlbif.eti.uva.nl/ccw/ (accessed January 25, 2011)
Savchenko E.N. 1986. [Limoniids (general charakteristics, subfamilies Pediciinae and Hexatominae)] // Fauna Ukrajiny. Vol.14. No.2. P.1-380 [in Russian].

Starý J. 2009. West Palaearctic species of the genus Eloeophila (Diptera: Limoniidae) // European Journal of Entomology. Vol.106. P.425-440. 